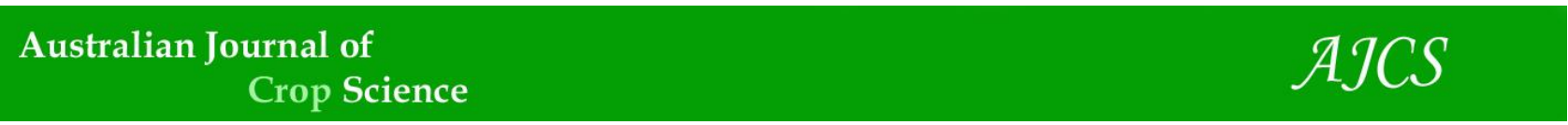

AJCS 15(06):835-841 (2021)

ISSN:1835-2707

doi: 10.21475/ajcs.21.15.06.p2917

\title{
Components of resistance to Olivea neotectonae in Tectona grandis Linn F. as a criterion for selecting promising genotypes
}

\author{
Antonio Marcos Chimello ${ }^{1,3 *}$, Jeferson Gonçalves de Jesus ${ }^{1}$, Suelene Surubi de Melo ${ }^{1}$, Isabela Vera dos \\ Anjos $^{1,3}$, Milson Evaldo Serafim², Kelly Lana Araújo ${ }^{1}$, Leonarda Grillo Neves ${ }^{1,3}$
}

\author{
'Universidade do Estado de Mato Grosso UNEMAT, Departamento de Agronomia, Cáceres -MT, Brasil \\ ${ }^{2}$ Instituto Federal de educação, ciência e tecnologia de Mato Grosso, Cáceres - MT, Brasil \\ ${ }^{3}$ Programa de Pós Graduação em Bitecnologia e Bidiversidade, Rede Pró Centro-Oeste, UNEMAT, Cáceres - MT, \\ Brasil
}

*Corresponding author: antoniokimelo@hotmail.com

\section{Abstract}

The aim of this paper was to identify the best components involving resistance to the $O$. neotectonae fungus, allowing for adequate selection of promising teak genotypes to explore in improvement programs or for disease management. Thirty different clonal teak genotypes were evaluated in a greenhouse from PROTECA Biotecnologia Florestal. The experimental design was a randomized block design with three replications and three plants per plot. The following characteristics were evaluated: average latent period, number of pustules per $\mathrm{cm}^{2}$, area below the number of pustules progress curve (ABNPPC), frequency of infection, and number of urediniospores per pustule. The data for the resistance characteristics were submitted to ANOVA and multivariate analysis applying grouping techniques and canonical variables. High genetic variability was observed among the $30 \mathrm{~T}$. grandis genotypes regarding resistance to the $O$. neotectonae fungus. Both for the Unweighted Pair Group Method with Arithmetic Mean (UPGMA), the canonical variables method and Best Linear Unbiased Prediction (BLUP) the genotypes that showed the greatest resistance to the fungus were genotypes 03 and 10.

Keywords: Teak, Forest species, Teak rusk, Clonal seedlings, REML/BLUP.

\section{Introduction}

Teak (Tectona grandis Linn F.) is a tree species belonging to the Lamiaceae family that produces exceptional wood that is highly valued in world trade (Li et al., 2016). The prospects for teak cultivation in the Center-West region, especially in the State of Mato Grosso, suggest a desirable and predictable economic return, given the region's edaphoclimatic conditions and some indicators in terms of production for the State (Medeiros et al., 2018). However, teak rust caused by the Olivea neotectonae (Pieri et al., 2011), belonging to the Filo Basidiomycota, Pucciniales Order, Chaconiaceae Family (Pieri et al., 2011; Céspedes et al., 2014), stands out as a yield reducing factor.

The first report of this disease in the American continent was in Panama in 2003 (Esquivel, 2003) and in the following year in Costa Rica (Arguedas, 2004), in Equador (Pinargote, 2004), and in Mexico by the North American Plant Protection Organization (NAPPO, 2005). In Brazil the first official report of the disease was in 2009 in the municipality of Sinop, MT (Bonaldo et al., 2011). Among teak leaf diseases, rust is the most important (Arguedas, 2004; Bonaldo et al., 2011), with severe epidemics causing rapid drying and loss of leaves in plants, which become weak and take significantly longer for wood production, becoming poor in quality (Cespedes and Yepes, 2007; Gasparotto e Pereira 2013). Studies in Cuba indicate that young trees suffer from loss of leaves around 20 to 30 days after symptoms start to appear, as well as exhibiting reduced growth (Pérez et al., 2009).

Generally, programs for the genetic improvement of teak concentrate on developing clones, with emphasis on rate of growth and wood properties, however not many programs exist for genetic improvement aimed at resistance to diseases. Thus, there is a noted need for improvement programs aimed at disease resistance in forest cultivations.

The REML/BLUP procedure (maximum restricted likelihood/best unbiased prediction), stands out as one of the main procedures for estimating genetic parameters in progeny tests. In light of this, the aim of this paper was to identify the best components involving resistance to the $O$. neotectonae fungus, allowing for adequate selection of promising teak genotypes to explore in improvement programs or for disease management.

Results

The analyzed resistance components presented a large quantitative variation between genotypes, as well as the Pearson linear correlation coefficients observed between the components being significant for the Infection Frequency $x$ ABNPPC, Infection Frequency $x$ Pustules per $\mathrm{cm}^{2}$, and ABNPPC $x$ Pustules per $\mathrm{cm}^{2}$ variables, with all of the significant 
correlations being positive and demonstrating the connection between the variables (Table 1).

Based on the relative magnitude of the Mahalanobis distance values obtained via the analyzed characteristics of resistance to the Olivea neotectonae fungus, the existence of genetic variability was verified by means of the UPGMA grouping method, obtaining the formation of four distinct groups (Table 2).

The first group was formed of two genotypes (03 and 10), with these being the genotypes that showed the greatest resistance to the Olivea neotectonae fungus, for the characteristics evaluated, and the genotypes representing group 1 are worth noting due to them exhibiting greater resistance characteristics than the other genotypes. In genotype 03 the first signs of disease were found at 19 days after inoculation (DAI), however at 20 DAl it did not reach the average latent period and spores were not found on the pustules present in this genotype. For the other characteristics the values were approximately 0 .

Then a group was formed with genotypes 13 and 18 . In this group the latent period was 16 days and spore production per pustule varied from 1154.1214 to 1206.0846 . However, when compared to the genotypes from the other groups, they were the ones that exhibited the highest infection frequency (0.0850 and 0.1382), ABNPPC (0.9538 and 0.6310), and pustules per $\mathrm{cm}^{2}$ (1.3306 and 0.8187).

The number three group exhibited a higher quantity of genotypes (23 genotypes), and in this group the latent period varied from 10 to 19 days, the infection frequency from 0.0026 to 0.0545 , the ABNPPC from 0.0207 to 0.3973 , the number of pustules per $\mathrm{cm}^{2}$ from de 0.0247 to 0.5250 , and the number of spores per pustule from 440.4762 to 1777.9982 .

And lastly, the group that exhibited the highest susceptibility to teak rusk was formed of genotypes 8,12 , and 7 . These genotypes exhibited a latent period from 14 to 15 days, the infection frequency varied from 0.0599 to 0.0837 , and the ABNPPC was between 0.3889 and 0.5283 . For the number of pustules per $\mathrm{cm}^{2}$ and number of spores per pustule variables, the values varied from 0.5763 to 0.8055 and 2040.4889 to 931.9924, respectively.

The canonical variables method aims to produce a bi or tridimensional scatterplot which can identify similar genotypes, making it possible to simplify the interpretation of the results. The viability of its interpretation is restricted to the variables which exceed $80 \%$ (Cruz et al., 2004). In this study, it was verified that the first three variables explain $89.86 \%$ of the total variance (Table 3 ).

Therefore, the use of the tridimensional scatterplot is justified by the analysis of the canonical variables, as these provide structural simplification of the data.

The genotype scatterplot using the canonical variables (Figure 1) presented a similar behavior to the grouping using the UPGMA method. However, genotype 7, which using the UPGMA method was allocated into group 04, being one of most susceptible to the Olivea neotectonae fungus, was in this case grouped into group two with genotypes 13 and 18 . In relation to the relative contribution of each characteristic of resistance to the Olivea neotectonae fungus (Table 4), based on the criterion proposed by Singh (1981), it was verified that for the 30 Teak genotypes analyzed we have, in descending order of contribution, Latent Period, Number of Pustules per $\mathrm{cm}^{2}$, Spores per Pustule, ABNPPC, and Frequency of Infection.
The Latent Period, Number of Pustules per $\mathrm{cm}^{2}$, and Spores per Pustule characteristics contribute to $82.48 \%$ of the total distribution.

\section{Estimation of genetic parameters and individual selection and estimates of gains}

By analyzing the variance components obtained by Restricted Maximum Likelihood (REML), it can be observed that the variable Latent Period presented the largest results of individual heritability in the broad sense and heritability of the genotype mean, with values of 0.29 and 0.77 , respectively (Table 5).

The variable spores per pustule was the variable that presented lower heritability values, this can be explained by the low value of $\sigma^{2} \mathrm{~g}$ and high value of $\sigma^{2} f$.

From the 30 genotypes evaluated, 10 best genotypes were selected through the estimates of the genetic gains predicted by BLUP, and the genetic gains were predicted and the new averages estimated (Table 6).

\section{Discussion}

This paper showed that for 30 teak genotypes evaluated for the existence of genetic variability with regards to resistance to the Olivea neotectonae fungus, the result was similar to that found by Xavier (2007), who in looking at the resistance of other forest species such as Eucalyptus globulus and Eucalyptus nitens to rust (Puccinia psidii), found variability among the species evaluated.

The results found in table 3 , is similar to that found by Barceli et al. (2011), who evaluated the severity of Olivea neotectonae fungus using the area below the disease progression curve for ten commercial clones over the period between May 2009 and July 2010, found that clones C9, C8, and $\mathrm{C} 10$ were most susceptible, clones $\mathrm{C} 4, \mathrm{C} 1, \mathrm{C} 3, \mathrm{C2}, \mathrm{C} 6$, and $\mathrm{C} 7$ exhibited intermediate resistance, while clone $\mathrm{C} 5$ proved to be the most resistant to teak rust.

The cophenetic correlation coefficient obtained between the Mahalanobis generalized distance matrix and the cophenetic distance matrix $(r=0.86)$ revealed a good adjustment between the graphic representation of the distances and the original matrix (Rohlf, 2000), allowing for inferences to be made by means of the visual evaluation in Table 03. In this type of graphic representation, the efficiency with which the original matrix of distance data is represented in the table directly implies the possibility of its use.

At some commercial teak plantations severely attacked by the $O$. neotectonea fungus in Panama and Costa Rica, trees that did not exhibit symptoms of the disease were detected (Arguedas, 2004). This was also shown at a teak plantation in the state of Mato Grosso and in the municipalities of Xinguara in Pará and in the state of São Paulo in the municipality of Mococa (Gasparotto et al., 2014), as was it recorded by Ferreira and Silva, (1982) in an experiment involving around eleven Eucalyptus spp species in the region of Espirito Santo, where it was found that the Eucalyptus torelliana and Eucalyptus brassiana did not exhibit symptoms of the disease. These results differ from that found in this paper, since no teak genotype immune to the $O$. neotectonae fungus was found.

However, the variability existing in the latent period, in the infection frequency, in the ABNPPC, in the number of spores per $\mathrm{cm}^{2}$, and in the number of spores per pustule, between the teak genotypes evaluated, showed a large quantitative variation in these characters, evidence of the occurrence of 
Table 1. Pearson correlation coefficients between the resistance components.

\begin{tabular}{|l|l|l|l|l|}
\hline Variables & Spores per Pustule & Average Latent Period & Infection Frequency \\
\hline Latent Period & $0.0191 \mathrm{~ns}$ & - & - & - \\
\hline Infection Frequency & $0.1017 \mathrm{~ns}$ & $0.0535 \mathrm{~ns}$ & - & - \\
\hline ABNPPC & $0.0706 \mathrm{~ns}$ & $0.0092 \mathrm{~ns}$ & $0.9845^{* *}$ & - \\
\hline Pustules per cm & $0.0527 \mathrm{~ns}$ & $0.1046 \mathrm{~ns}$ & $0.9417^{* *}$ \\
\hline
\end{tabular}

${ }^{\mathrm{n}}$ Not significant**Significant to $1 \%$ probability

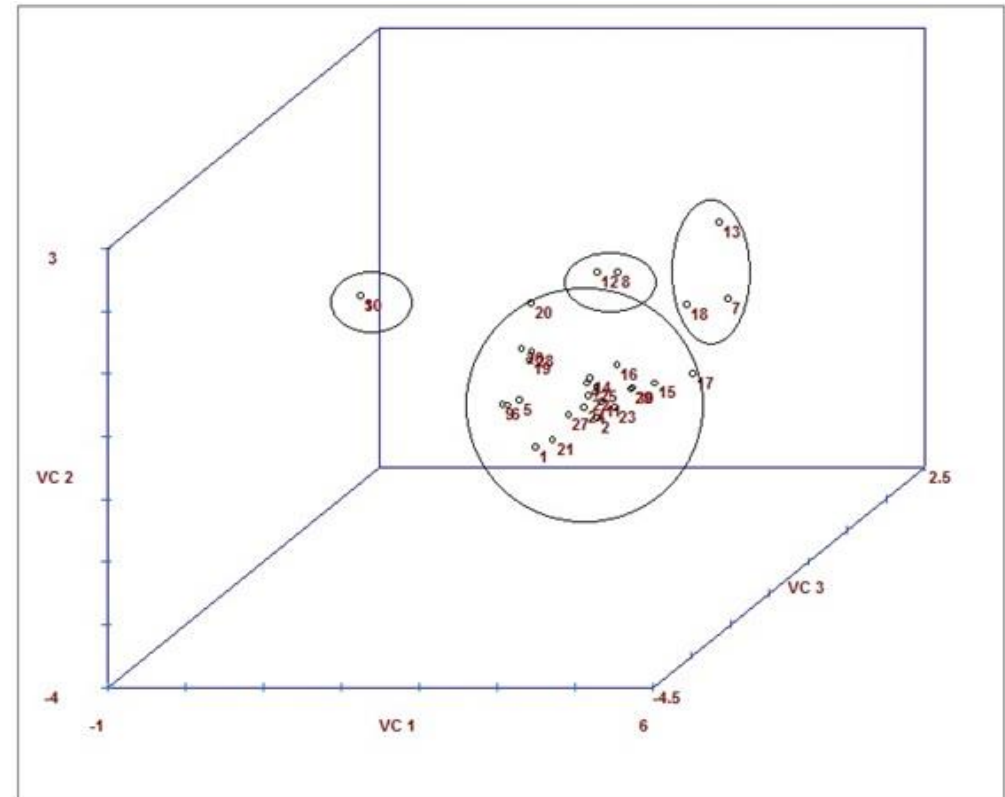

Figure 1. scatterplot $3 \mathrm{D}$ of the 30 Tectona grandis genotypes, in relation to the first three canonical variables $\left(\mathrm{CV}_{1}\right.$, $\mathrm{CV}_{2}$, and $\left.\mathrm{CV}_{3}\right)$.

Table 2. Epidemiological variables presented by the teak genotypes infected by 0 . neotectonae ${ }^{(1)}$.

\begin{tabular}{|c|c|c|c|c|c|c|}
\hline Genotypes & $\begin{array}{l}\text { Average Latent } \\
\text { Period (days) }\end{array}$ & $\begin{array}{l}\text { Infection } \\
\text { Frequency }\end{array}$ & ABNPPC & $\begin{array}{l}\text { Pustules per } \\
\mathrm{cm} 2\end{array}$ & $\begin{array}{l}\text { Spores per } \\
\text { Pustule }\end{array}$ & Groups ${ }^{(2)}$ \\
\hline 10 & 0 & 0 & 0 & 0 & 0 & I \\
\hline 18 & 16 & 0.0850 & 0.6310 & 0.8187 & 1206.0846 & II \\
\hline 1 & 19 & 0.0097 & 0.0687 & 0.0929 & 447.8114 & III \\
\hline 5 & 15 & 0.0149 & 0.1014 & 0.1432 & 489.4026 & III \\
\hline 6 & 13 & 0.0026 & 0.0207 & 0.0247 & 550.5051 & III \\
\hline 9 & 14 & 0.0088 & 0.0490 & 0.0844 & 440.4762 & III \\
\hline 11 & 16 & 0.0132 & 0.0992 & 0.1274 & 1153.1085 & III \\
\hline 14 & 16 & 0.0350 & 0.2399 & 0.3369 & 867.8838 & III \\
\hline 20 & 10 & 0.0545 & 0.3973 & 0.5250 & 467.5926 & III \\
\hline 21 & 19 & 0.0113 & 0.0716 & 0.1084 & 612.7900 & III \\
\hline 22 & 15 & 0.0164 & 0.1374 & 0.1578 & 1012.0321 & III \\
\hline 23 & 17 & 0.0159 & 0.1313 & 0.1530 & 1167.2263 & III \\
\hline 24 & 18 & 0.0214 & 0.1376 & 0.2060 & 885.5219 & III \\
\hline 25 & 18 & 0.0410 & 0.2779 & 0.3944 & 787.1840 & III \\
\hline 26 & 13 & 0.0273 & 0.1467 & 0.2631 & 642.8571 & III \\
\hline 27 & 17 & 0.0186 & 0.1401 & 0.1786 & 734.0700 & III \\
\hline 28 & 10 & 0.0238 & 0.1963 & 0.2294 & 669.4866 & III \\
\hline 29 & 16 & 0.0224 & 0.1760 & 0.2152 & 1296.3028 & III \\
\hline
\end{tabular}


Table 3. Estimate of Auto-Values associated with the spread for variables evaluated in Teak Genotypes.

\begin{tabular}{|l|l|l|}
\hline Root & Root \% & Accumulated \% \\
\hline 1.0899961 & 46.0557273 & 46.0557273 \\
\hline 0.70652 & 29.8526695 & 75.9083968 \\
\hline 0.3303636 & 13.9588881 & 89.8672849 \\
\hline 0.2398083 & 10.1326458 & 99.9999308 \\
\hline 0.0000016 & 0.0000692 & 100.0 \\
\hline
\end{tabular}

Table 4. Estimate of the relative contribution of the characteristics of resistance to the Olivea neotectonae (S.j) fungus for the genetic divergence among 30 Teak genotypes, based on the Mahalanobis generalized distance.

\begin{tabular}{|l|l|l|}
\hline \multicolumn{1}{|l|}{ Variables } & Relative contribution & \\
\hline & S. j. & \\
\hline Average Latent Period & 686.500395 & 33.6125 \\
\hline Pustules per $\mathrm{cm}^{2}$ & 551.408022 & 26.9981 \\
\hline Spores per Pustule & 446.859692 & 21.8792 \\
\hline ABNPPC & 323.493254 & 15.8389 \\
\hline Frequency of Infection & 34.132863 & 1.6712 \\
\hline
\end{tabular}

Table 5. Estimates of components genotypic variance between genotypes $\left(\sigma_{\mathrm{g}}^{2}\right)$, individual phenotypic variance $\left(\sigma_{\mathrm{f}}^{2}\right)$, broad sense individual heritability $\left(h^{2} \mathrm{~g}\right)$, heritability of genotype mean $\left(\mathrm{h}^{2} \mathrm{mc}\right)$, accuracy of genotype selection (Acclon) and overall average, obtained by the REML procedure for the five traits evaluated in 30 teak genotypes resistant to the fungus $O$. neotectonae.

\begin{tabular}{|c|c|c|c|c|c|c|}
\hline $\begin{array}{l}\text { Parameters } \\
\text { Genetics }\end{array}$ & $\sigma_{\mathrm{g}}^{2}$ & $\sigma_{f}^{2}$ & $\mathbf{h}_{g}^{2}$ & $\mathrm{~h}^{2} \mathrm{mc}$ & Acclon & $\begin{array}{l}\text { Média } \\
\text { Geral }\end{array}$ \\
\hline Average Latent Period (days) & 20.6146 & 70.2749 & 0.29334 & 0.7788 & 0.8825 & 17.8148 \\
\hline Infection Frequency & 0.0004 & 0.0047 & 0.0988 & 0.4940 & 0.7028 & 0.0306 \\
\hline ABNPPC & 0.0207 & 0.2240 & 0.0924 & 0.4755 & 0.6896 & 0.2111 \\
\hline Pustules per $\mathrm{cm}^{2}$ & 0.0436 & 0.4417 & 0.0988 & 0.4940 & 0.7028 & 0.2950 \\
\hline Spores per Pustule & 91149.9696 & 1186875.9011 & 0.0767 & 0.4184 & 0.6468 & 916.3875 \\
\hline
\end{tabular}

ABNPPC: Area Below the Number of Pustules Progression Curve.

Table 6. Ranking of the five teak genotypes with highest estimates of genetic gain and new predicted averages, estimated by REML/BLUP, in relation to genetic resistance to $O$. neotectonae.

\begin{tabular}{|c|c|c|c|c|c|c|c|c|c|c|c|c|c|c|c|}
\hline \multirow[t]{2}{*}{ Ord } & \multirow{2}{*}{ 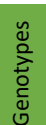 } & \multicolumn{2}{|c|}{$\begin{array}{l}\text { Average Latent } \\
\text { Period (days) }\end{array}$} & \multirow{2}{*}{ 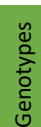 } & \multicolumn{2}{|c|}{ Infection Frequency } & \multirow{2}{*}{$\begin{array}{l}\tilde{y} \\
\sum_{2}^{0} \\
0 \\
0 \\
0 \\
0\end{array}$} & \multicolumn{2}{|l|}{ ABNPPC } & \multirow{2}{*}{$\begin{array}{l}\tilde{y} \\
\sum^{0} \\
\stackrel{0}{0} \\
\stackrel{0}{0} \\
0\end{array}$} & \multicolumn{2}{|c|}{ Pustules per $\mathrm{cm}^{2}$} & \multirow{2}{*}{ 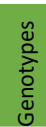 } & \multicolumn{2}{|c|}{ Spores per Pustule } \\
\hline & & $\begin{array}{l}\text { Gain } \\
(\%)\end{array}$ & $\begin{array}{l}\text { New } \\
\text { average }\end{array}$ & & $\begin{array}{l}\text { Gain } \\
\text { (\%) }\end{array}$ & $\begin{array}{l}\text { New } \\
\text { average }\end{array}$ & & Gain (\%) & $\begin{array}{l}\text { New } \\
\text { average }\end{array}$ & & $\begin{array}{l}\text { Gain } \\
(\%)\end{array}$ & $\begin{array}{l}\text { New } \\
\text { average }\end{array}$ & & $\begin{array}{l}\text { Gain } \\
\text { (\%) }\end{array}$ & $\begin{array}{l}\text { New } \\
\text { average }\end{array}$ \\
\hline 1 & 10 & 62.12 & 28.86 & 10 & 0.00 & 0.04 & 10 & 0.00 & 0.24 & 10 & 0.00 & 0.34 & 10 & 0.00 & 1007.96 \\
\hline 2 & 3 & 58.12 & 28.17 & 3 & 1.63 & 0.04 & 3 & 1.66 & 0.24 & 3 & 1.69 & 0.34 & 3 & $1 . .44$ & 998.60 \\
\hline 3 & 6 & 50.84 & 26.87 & 6 & 3.59 & 0.03 & 6 & 3.41 & 0.24 & 6 & 3.52 & 0.33 & 9 & 2.99 & 989.50 \\
\hline 4 & 9 & 44.53 & 25.75 & 2 & 5.22 & 0.03 & 9 & 5.11 & 0.23 & 2 & 5.32 & 0.33 & 1 & 3.90 & 980.07 \\
\hline 5 & 1 & 39.28 & 24.81 & 9 & 6.85 & 0.03 & 2 & 6.72 & 0.23 & 9 & 6.95 & 0.32 & 20 & 4.88 & 970.38 \\
\hline 6 & 25 & 35.54 & 24.15 & 1 & 8.48 & 0.03 & 1 & 8.38 & 0.23 & 1 & 8.64 & 0.32 & 5 & 5.89 & 961.08 \\
\hline 7 & 19 & 32.80 & 23.66 & 21 & 10.44 & 0.03 & 21 & 10.09 & 0.22 & 21 & 10.41 & 0.31 & 6 & 6.95 & 952.16 \\
\hline 8 & 26 & 30.74 & 23.39 & 19 & 12.07 & 0.03 & 19 & 11.89 & 0.22 & 19 & 12.24 & 0.31 & 21 & 7.98 & 943.77 \\
\hline 9 & 21 & 28.28 & 22.85 & 11 & 14.03 & 0.03 & 11 & 13.64 & 0.21 & 11 & 14.10 & 0.30 & 26 & 8.97 & 929.61 \\
\hline 10 & 15 & 25.87 & 22.42 & 5 & 15.99 & 0.03 & 5 & 15.48 & 0.21 & 5 & 16.10 & 0.30 & 28 & 9.99 & 916.39 \\
\hline
\end{tabular}

\begin{tabular}{|c|c|c|c|c|c|}
\hline Treatment & Genotype code & Origin & Treatment & Genotype code & Origin \\
\hline 1 & $\mathrm{~A} 2$ & \multirow{10}{*}{ Solomon Islands } & 16 & B17 & Brazil \\
\hline 2 & A3 & & 17 & $\mathrm{C} 1$ & \multirow[t]{3}{*}{ Malaysia } \\
\hline 3 & A4 & & 18 & $\mathrm{C} 2$ & \\
\hline 4 & A6 & & 19 & $\mathrm{C5}$ & \\
\hline 5 & A7 & & 20 & D2 & \multirow[t]{3}{*}{ India } \\
\hline 6 & A8 & & 21 & D3 & \\
\hline 7 & A9 & & 22 & D4 & \\
\hline 8 & A10 & & 23 & E2 & \multirow[t]{2}{*}{ Indonesia } \\
\hline 9 & $\mathrm{~A} 11$ & & 24 & E4 & \\
\hline 10 & $\mathrm{~A} 12$ & & 25 & G1 & \multirow[t]{2}{*}{ Costa do Marfim } \\
\hline 11 & B2 & \multirow[t]{5}{*}{ Brazil } & 26 & G2 & \\
\hline 12 & B6 & & 27 & $\mathrm{J1}$ & \multirow[t]{2}{*}{ Ghana } \\
\hline 13 & B8 & & 28 & 12 & \\
\hline 14 & B14 & & 29 & T4 & \multirow[t]{2}{*}{ Tanzania } \\
\hline 15 & B16 & & 30 & T8 & \\
\hline
\end{tabular}


partial resistance in the genotypes tested, since according to Parlevliet (1985), quantitative or partial resistance acts via a reduction in infection rate, a decrease in spore production, a reduction in the size of the pustules, and an increase in the latent period.

By analyzing the variance components obtained by Restricted Maximum Likelihood (REML), the average heritability value was similar to that found by Rachid et al. (2013), that in their study of Eucalyptus resistance to rust found a value of 0.83 . The accuracy of the selection of the genotypes varied from 0.64 to 0.88 , which indicates a good precision of the results according to Resende (2002).

The result of the REML / BLUP method was similar to multivariate analysis based on the relative distance of Mahalanobis, as it can be seen that genotypes 10 and 03 were listed as superior in terms of resistance to the fungus $O$. neotectonae, however the next ranking genotype was the genotype 06 for most of the evaluated characteristics, and genotype 09 for the characteristic of Number of Urediniospores per pustule, as shown in Table 7.

The fact that genotypes 10 and 03 are resistant in both analyzes performed in this work, is explained by the variable Latency Period, as it is related to the effectiveness of the plant's resistance to pathogen infection. According to the literature, it is common to find variation in the rust latent period, as this can occur according to specific characteristics of the host, pathogen, environmental conditions and evaluation method (Castro et al., 1985; Habtu and Zadoks, 1995; Rosado, 2007; Ferreira et al., 2017). Similar values for the latent period variable were found by Ferreira et al. (2017), in their work with selection of resistant eucalyptus genotypes, where the authors found a latent period of up to 18 days.

\section{Materials and methods}

\section{Study location}

This paper was developed at the Cáceres University Campus of the State University of Mato Grosso - UNEMAT, at 16 $11^{\prime}$ $42^{\prime \prime}$ South latitude and 570 40' 51" West longitude, $210 \mathrm{~km}$ from Cuiabá.

Thirty different clonal teak genotypes selected at a greenhouse belonging to the PROTECA Forest Biotechnology company (Table 7) were evaluated. The experimental design was one of randomized blocks, with three repetitions, and each segment was composed of three plants. The seedlings were initially planted with $10 \mathrm{~cm}$ in height in 2 liter vases containing a mixture of earth and sand in a 3:1 proportion. Fertilization was carried out once a week using $100 \mathrm{~mL}$ of nutritive solution (Clarck, 1975). Irrigation was carried out manually without wetting the leaves and 3 second nebulizations were carried out every $10 \mathrm{~min}$ in order to keep the air humidity high.

PROTECA Forest Biotechnology is a company that has been specialized in the clonal propagation of teak for more than 10 years and holds an exclusive collection of superior genotypes of this forest species.

\section{Obtaining urediniospores}

The inoculum used came from teak leaves collected in the region of Cáceres-MT with symptoms of rust. The urediniospores were collected by scratching the leaves with a brush and a suspension of spores was subsequently prepared with distilled water and tween 80 (0.075\%). The concentration of the suspension was adjusted to $2 \times 10^{4}$ spores per $\mathrm{mL}$ of water with the help of a Neubauer chamber (Sood et al., 2009).

\section{Inoculation}

Inoculation of the genotypes was carried out 36 days after transplanting the seedlings, using approximately $11 \mathrm{~mL}$ of the suspension per plant. The inoculation was carried out by spraying all of the leaves with the help of a manual sprayer. After inoculation the genotypes were covered with black bags for 24 hours (humid chamber). The plants were kept in a greenhouse throughout the whole period of the experiment. The maximum and minimum temperatures recorded on the day of inoculation were 16.4 and $27.6 \% \mathrm{C}$, respectively, and the averages during the whole experiment were a minimum of 22.08 and a maximum of $34.02^{\circ} \mathrm{C}$.

After inoculation, two leaves from the middle third of each plant were selected for the evaluations and the leaves were analyzed up until the $20^{\text {th }}$ day after inoculation.

\section{Evaluation of traits}

- Average latent period: interval, in days, between inoculations until the appearance of pustules sporing on $50 \%$ of the leaves marked by repetition per genotype (Griffiths and Jones, 1987).

- Number of pustules per $\mathrm{cm}^{2}$ : the total pustules present on each marked leaf was counted daily. To calculate the area of each leaf, at the end experiment the marked leaves were collected and digitalized. Then, measurement was carried out of the total area of each leaf with the help of the ImageJ computer program. The number of pustules per $\mathrm{cm}^{2}$ for each evaluation was calculated by dividing the number of pustules by the total leaf area of each marked leaf.

- Area Below the Number of Pustules Progression Curve (ABNPPC): With the daily values of the number of pustules per $\mathrm{cm}^{2}$, the ABNPPC was calculated based on the equation proposed by Shaner and Finney (1977).

$A B N P P C=$

$$
\sum_{i=1}^{n-1}\left[\frac{\left(Y_{i}+Y_{i+1}\right)}{2}\right]\left(t_{i+1}-t_{i}\right)
$$

Where $\mathrm{n}$ is the number of evaluations, $\mathrm{ti+1}-\mathrm{ti}$ is the interval between two evaluations, and $\mathrm{Yi}$ and $\mathrm{Yi}+1$ are two consecutive evaluations carried out at times ti+1 and ti.

- Frequency of infection: The frequency of infection was estimated by dividing the average number of urediniospores deposited per $\mathrm{cm}^{2}$ by the number of pustules formed per $\mathrm{cm}^{2}$ of leaf area. To calculate the average number of urediniospores deposited on the leaves at the time of inoculation, microscope slides were sprayed with the spore suspension in the same way described for the plant inoculation. Then, the total number of spores deposited $/ \mathrm{cm}^{2}$ on each slide was counted, with the help of an optical microscope. For calculating the frequency of infection, the number of pustules formed per $\mathrm{cm}^{2}$ of leaf area on the last day of evaluation for each marked leaf was considered.

- Number of urediniospores per pustule: To the counting of the number of spores produced per pustule, for these counts, three $1 \mathrm{~cm}^{2}$ segments from the most affected areas of each marked leaf were removed. Then, the segments were conditioned in $1.5 \mathrm{~mL}$ microtubules, into which $1 \mathrm{~mL}$ of distilled water solution $+0,075 \%$ Tween 80 was added. Subsequently, the microtubules were shaken in a vortex orbital shaker for $30 \mathrm{~min}$, so that the urediniospores were released into the solution. Then, the segments were removed and placed onto petri plates to count the number of pustules. This count was carried out using a stereoscopic microscope. 
- Quantification of the number of urediniospores was carried out with the help of a Neubauer chamber. These data were used for quantifying the number of urediniospores produced per pustule.

\section{Statistical analysis}

The data on resistance characteristics were submitted for variance analysis and tested for significance via the $\mathrm{F}$ test, using the Genes program (Cruz, 2013).

A multivariate analysis was carried out regarding the resistance characteristics, by applying grouping and canonical variable techniques. For the grouping technique, the Mahalanobis generalized distance (Mahalanobis, 1936) was used as a measure of dissimilarity, and for delineating the groups, using the average link between groups (UPGMA) grouping method was used, with the adjustment between the distance matrix and the dendrogram being estimated by the Cophenetic Correlation Coefficient (CCC) (Sokal and Rohlf, 1962).

For the analysis of canonical variances, the genetic diversity was shown by means of a 3D projection of the first three variables. The relative contribution of the characters using the Mahalanobis generalized distances was also added, applying the criterion proposed by Singh (1981) and the Pearson linear correlation analysis. All of the statistical analyses were carried out using the Genes computer program (Cruz, 2013).

\section{REML/BLUP}

To estimate the parameters and select the best genotypes for the characteristics of resistance to the fungus $O$. neotectonae, the REML/BLUP mixed model methodology was used, for the estimation of the variance components by the restricted maximum likelihood (REML) method and the prediction of genotypic values by the best unconverted linear prediction (BLUP) (Resende, 2002; Alves and Resende, 2008).

The analyzes by mixed models REML/BLUP were performed using the Selegen-Reml/Blup program (Resende, 2016), which follows the statistical model $y=X r+Z g+W p+e$, where $y$ is the data vector, $r$ is the vector of repeating effects (assumed to be fixed) plus the general average, $g$ is the vector of genotypic effects (assumed to be random), $p$ is the vector of plot effects, $e$ is the vector of errors or residuals (random). Capital letters represent the incidence matrices for these purposes. The statistical model used was the 02 of the Selegen program.

The following variance components were estimated (REML): $\sigma^{2}$ : genotypic variance;

$\sigma^{2}$ : individual phenotypic variance;

$\mathrm{h}^{2} \mathrm{~g}$ : individual heritability in the broad sense, that is, from the total genotypic effects;

$\mathrm{h}^{2} \mathrm{mc}$ : heritability of the genotype mean, assuming no loss of plots and

Acclon: accuracy of genotype selection, assuming no plot loss.

\section{Conclusion}

It can be concluded that genetic variability exists among the 30 Tectona grandis genotypes from the PROTECA Company with regards to resistance to the Olivea neotectonae fungus. For both the mean group bonding method (UPGMA), the canonical variable method and the best non-biased linear prediction (BLUP), the genotypes that presented the highest resistance to the fungus Olivea neotectonea were genotypes 03 (A4) and 10 (A12), both from Solomon Islands, and should continue the teak breeding program.

\section{Acknowledgments}

Research supported by FAPEMAT and CAPES.

\section{Conflict of interest}

The authors declare that they have no conflict of interest.

\section{Ethical standards}

The experiments shown in the manuscripts submitted for publication comply with the current laws of the country in which they were performed.

\section{References}

Alves FM, Resende MDV (2008) Avaliação genética de indivíduos e progênies de cupuaçuzeiro no estado do Pará e estimativas de parâmetros genéticos. Revista Brasileira de Fruticultura. 30(1): 696-701.

Arguedas M (2004) La roya de la teca Olivea tectonae (Rac.): consideraciones sobre su presencia en Panamá y Costa Rica. Kurú: Revista Forestal. 1(1): 1-16.

Barceli AC, Bonaldo SM, Raasch-Fernandes LD (2011) Severidade de ferrugem (Olivea tectonae) em diferentes clones de teca no norte de Mato Grosso. Scientific Electronic Archives. 12(2): 42 - 46. Retrieved February, 2020,

from

http://www.seasinop.com.br/revista/index.php?journal= SEA\&page $=$ view\&path\%5B\%5D=663\&path\%5B\%5D=pdf.

Bonaldo SM, Barceli AC, Trento RA, Gasparotto F, Taffarel C (2011) Relato oficial da ocorrência de Olivea tectonae em teca (Tectona grandis) no Brasil. Summa Phytopathologica. 37(1): 153.

Castro HA, Krugner TL, Bergamin Filho A (1985) Especialização fisiológica no sistema Eucalyptus grandis - Puccinia psidii Winter. Ciência e Prática. 9(1): 80-92.

Cespedes PB, Yepes MS (2007) New records of potentially important rust (Uredinales) in Colombia. National Faculty of Agronomy Magazine. 60(1): 3645-3655.

Clarck RB (1975) Characterization of phosphates in intact maize roots. Journal of Agricultural and Food Chemistry. 23(1): 458-460.

Cruz CD, Regazzi AJ, Carneiro PCS (2004) Modelos biométricos aplicados ao melhoramento genético, Universidade Federal de Viçosa 3rd edn: 480, Brazil.

Cruz, C.D. (2013) Genes a software package for analysis in experimental statistics and quantitative genetics. Acta Scientiarum. 1(1): 1807-8621.

Esquivel E (2003) La roya de la teca (Tectona grandis L.; Verbenaceae) causada por Olivea tectonae (T.S. \& K. Ramak) Mulder (Chaconiaceae) en Panamá - primer reporte en América. Hoja Informativa Técnica sobre Ciencias Agrícolas en la República de Panamá, Agrociencia Panamensis. 3(4): 2.

Ferreira FA, Silva AR (1982) Comportamento de procedências de Eucalyptus grandis e de E. saligna à ferrugem (Puccinia psidii). Fitopatologia Brasileira. 7(1): 287-288.

Ferreira KCZ, Marino CL, Furtado EL (2017) Seleção de genótipos de eucalipto resistentes à ferrugem (Puccinia psidii) através de parâmetros monocíclicos. Summa Phytopathologica. 43(2): 103-110.

Gasparotto L, Bentes JLS, Pereira JCR (2014) Doenças de espécies florestais arbóreas nativas e exóticas na Amazônia, Embrapa. 1(1): 178. 
Gasparotto L, Pereira JCR (2013). A ferrugem da teca no estado do Amazonas. (Comunicado técnico, 101). 1 ed. Embrapa Amazônia Ocidental, Manaus, 4p.

Griffiths HM, Jones DG (1987) Components of partial resistance as criteria for identifying resistance. Annals of Applied Biology. 110(1): 603-610.

Habtu A, Zadoks JC (1995) Components of partial resistance in Phaseolus beans against an Ethiopian isolate of bean rust. Euphytica 83:95-102. Available at: https://link.springer.com/article/10.1007/BF01678035 Accessed Feb 12, 2020.

Li B, Cantino PD, Olmstead RG, Bramley GLC, Xiang CL, Ma ZH, Tan YH, Zhang DX (2016). A large-scale chloroplast phylogeny of the Lamiaceae sheds new light on its sub familial classification. Sci Rep. 6: 3434.

Mahalanobis PC (1936) On the generalized distance in statistics. Proceedings of the National Institute of Sciences of India 2(1): 49-55. Retrieved February, 2020, from http://bayes.acs.unt.edu:8083/BayesContent/class/Jon/Mi scDocs/1936 Mahalanobis.pdf

Medeiros RA, Paiva HN, Marcatti G (2018). Tectona grandis: zoneamento ecológico para o cultivo no estado de Mato Grosso, Brasil. Beau Bassin: Novas Edições Acadêmicas. 1(1): 1.

NAPPO (2005) Phitosanitary Alert System. Detection of powdery mildew (Olivea neotectonae), (Rac.) Thirum. Chaconiaceae, in the municipality of Las Choapas, Veracruz, Mexico 1(1): 1. Retrieved February, 2020, from http//www.pestalert.org;espanhol/oprDetail.cfm?opriD=1 42.

Parlevliet JE (1985) Resistance of the nonrace-specifi c type. In: Bushnell WR, Roelfs AP (Ed.) The cereal rusts: diseases, distribution, epidemiology and control. Academic Press 1(1): 501-525.

Pérez M, López MO, Martí O (2009) Olivea tectonae, leaf rust of teak, occurs in Cuba. New Disease Reports. 7(1): 32. London.

Pieri C, Passador MM, Furtado EL, Carvalho Junior AA (2011) Ferrugem da teca (Olivea neotectonae): novas ocorrências no Brasil e revisão do nome específico. Summa Phytopathol. 37(1): 199-201.

Pinargote CB (2004) Roya de la teca en Ecuador. In: Macías J, Arguedas M, Hilje L, Zanuncio JC (Ed). Plagas Forestales Neotropicales. Manejo integrado de Plagas y Agroecologia. 72(1): 91. Retrieved February, 2020, from http://web.catie.ac.cr/informacion/RMIP/rev72/Boletin\%2 OPF.pdf?CodSeccion $=48$.
Rachid LV, Moraes CB, Abílio FM, Zimback L, Costa RML, Mori ES (2013) Variabilidade genética em progênies de polinização controlada de Eucalyptus para resistência à ferrugem. 70 Congresso Brasileiro de Melhoramento de Plantas. Retrieved February, 2020, from https://www.researchgate.net/publication/299991668_Va riabilidade_genetica_em_progenies_de_polinizacao_contr olada_de_Eucalyptus_para_resistencia_a_ferrugem.

Resende MDV (2002) Genética biométrica e estatística no melhoramento de plantas perenes. Colombo: Embrapa Floresta; Brasília: Informação Tecnológica, 1 rd edn, Brasília, Brazil.

Resende MDV (2016) Software Selegen-REML/BLUP: a useful tool for plant breeding. Crop Breed Appl Biotechnol. 16(1): 330-339.

Rohlf FJ (2000) NTSYS-pc: numerical taxonomy and multivariate analysis system, version 2.1. New York: Exeter Software: 38. Retrieved February, 2020, from https://www.researchgate.net/publication/246982444_NT SYS-pc_-_Numerical

Taxonomy and Multivariate_Analysis_System

Rosado TB (2007) Mapeamento de gene letal, responsável pela distorção de segregação e detecção de QTL para resistência a ferrugem (Puccinia psidii) em Eucalyptus spp. Tese de Doutorado. Universidade Federal de Viçosa. Retrieved February, 2020, from https://www.locus.ufv.br/handle/123456789/1270.

Shaner G, Finney RE (1977) The effect of nitrogen fertilization on the expression of slow-mildewing resistence in knox wheat. Phytopathology. 67(1): 1051-1056.

Singh D (1981) The relative importance of characters affecting genetic divergence. The Indian Journal of Genetic and Plant Breeding 41: 237-245. Retrieved February, 2020, from https://www.indianjournals.com/ijor.aspx?target=ijor:ijgp b\&volume $=41$ \&issue $=2$ \&article $=010$.

Sokal RR, Rohlf FJ (1962) The comparison of dendrograms by objective methods. Taxonomy. 11(1): 30-40. Retrieved February, 2020, from https://www.jstor.org/stable/pdf/1217208.pdf?seq=1

Sood SG, Comstock JC, Glynn NC (2009) Leaf whorl inoculation method for screening sugarcane rust resistance. Plant Disease. 93(1): 1335.

Xavier AA, Sanfuentes EV, Junghans DT, Alfenas AC (2007) Resistência de Eucalyptus globulus e Eucalyptus nitens à ferrugem (Puccinia psidii). Revista Árvore. 31(1): 731-735. 